\title{
LONG-TERM EFFECT OF CONVENTIONAL MANAGEMENT ON PROPERTIES OF A SANDY SOIL
}

\author{
Jorge Garcia $^{\mathrm{a}}$, Maria Elena Ruiz ${ }^{\mathrm{a}}$, Nilda Castillo ${ }^{\mathrm{b}}$, Lazara Rangel ${ }^{\mathrm{a}}$ \\ ${ }^{a}$ Universidad Agraria de la Habana, San José de la Lajas, \\ Autopista Nacional y Carretera de Tapaste, Mayabeque, 32700, Cuba. \\ bUniversidad Politécnica Territorial José Antonio Anzoátegui, \\ El Tigre, Anzoátegui, Venezuela. \\ DOI: https://doi.org/10.51193/IJAER.2021.7302
}

\section{ABSTRACT}

In Venezuela the sustainable food production and environmental quality is threatened by soil degradation in the Venezuelan plains. Scarce information of the main types and processes of soil degradation these soils are available. As a support to near future management decisions, the objective of this work is to assess the impact of long-term effect of conventional management on several physical and chemical soil properties, soil penetration resistance and soil water infiltration in a sandy soil with different agricultural managements on the Mesa de Guanipa. Soil samples were taken in a stratified-random unaligned grid. There are significant differences between forest and conventional land use in the phosphorous content $\left(\mathrm{P}^{3+}\right)$ calcium $\left(\mathrm{Ca}^{2+}\right)$, magnesium $\left(\mathrm{Mg}^{2+}\right)$, soil organic matter (SOM), penetration resistance (PR) and soil infiltration. However, there are no significant differences for the bulk density $\left(\rho_{b}\right)$ between managements. These differences are associated to conventional management that affect the physical qualities, especially the adverse consequences in the soil mechanical resistance and infiltration capacity of sandy soils in the Mesa de Guanipa.PR in the subsoil of intensively cultivated soil exceeds the value of no- tillage more than 2 times. The average effective penetration is $0.27 \mathrm{~cm} / \mathrm{blows}$ for the disturbed soil and $0.39 \mathrm{~cm} /$ blows for the undisturbed. Initial and final soil infiltration rate of the no-tillage exceeds the value of tillage in 2 and 5 times, respectively. The adoption of conservation practices is crucial for their sustainability on the medium and long term.

Keywords: Tillage, Soil infiltration, Dynamic cone penetrometer, Effective penetration.

\section{INTRODUCTION}

Production of all crops involves the use of some type of tillage system. On the one hand, the tillage system may be very simple, involving either digging or punching holes to sow seeds. On 
International Journal of Agriculture and Environmental Research

ISSN: 2455-6939

Volume: 07, Issue: 03 "May-June 2021"

the other hand, it may be a complex system comprised of primary tillage and several secondary tillage operations before and after crop establishment, with different machinery and equipment.

The growing demand for food for the population has led to the intensive exploitation of agricultural soils; generally based on mechanization with tractors and plows unsuitable for one or another soil condition. According with FAO (1994), one of the main causes of soil degradation in Latin America is unquestionably the application. Of inadequate tillage techniques, with the consequent decline of physical, chemical and biological soil properties, the decrease in agricultural yields and more importantly, the deterioration of the environment.

In Venezuela also there is the trend of degradation of agricultural soils, whose severity is due to excessive use of machinery and inputs (fertilizers and pesticides), among other aspects (Pla, 1990; Mogollón and Comerma, 1994; Mazzani, 1999; Lozano et al., 2002 and Rodríguez et al., 2003).

Conventional tillage carried out in Venezuela is very complex due to the optimal water content conditions necessary for primary and secondary tillage. In addition, the opportune operational times are very short, creating bottlenecks in the production process due to the rain factor; also involves high costs. The disc harrow is the most common implement in agricultural fields, generally used for secondary tillage, due to inadequate friability conditions, timely operation time, relatively cheaper purchase price, ease use and maintenance, easier and faster weed control, as well as lime application (Hossne, 2006).

The region of the plains occupies the central part of Venezuela, represent an area of $260000 \mathrm{~km}^{2}$, about 5 percent of the total area of the country (Cárdenas et al. 2000). In its eastern portion, the area of the Mesa de Guanipa, Anzoátegui State, have a marked pattern in terms of frequency and variability of the rainfall, a large underground aquifer and around 300 thousand hectares of very coarse-textured soil destined to agricultural activities for agricultural production companies, which have a high degree of mechanization.

According with Bruand et al. (2005), sandy soils are often considered as soils with physical properties that are easily defined; however they are far from being simple. This is particularly the case for sandy soils in the tropics where they are subjected to a cycle of wetting and drying associated with seasonality. In this respect, small changes in composition lead to significant differences of physical properties.

Sandy soils are often considered as structurally inert because of their massive structure and the absence of shrink-swell properties (Lesturgez et al., 2005). In contrast, unlike other soils, the elementary fabric can be easily loosened by tillage practices. Thus greater porosity can be produced easily by tillage but its stability is very weak and compaction by wheels or other actions can produce a dense structure with adverse physical properties. This leads to a decrease 
International Journal of Agriculture and Environmental Research

ISSN: 2455-6939

Volume: 07, Issue: 03 "May-June 2021"

in the water retention properties and hydraulic conductivity, an increase in the resistance to penetration and sensitivity to surface crusting (Bruand et al. (2005).

Soil compaction affects important surfaces in the Venezuelan plains, fundamentally those that are highly mechanized, restricting root development and the movement of water in the soil profile. The structure of sandy soils can be easily affected by mechanical compaction over a large range of scales (Bruand et al., 2005). The low stability of aggregates causes the formation of surface crusting and consequently affects the water movement, causing a degradation of the soil structure. The main source of pollution is associated with commercial agriculture, while the excessive use of fertilizers and pesticides cause health problems, superficial contaminations, underground water bodies and losses of biodiversity (López et al., 2015).

The aim of this paper was to assess the impact of long-term effect of conventional management on some physical, chemical, mechanical and hydraulic properties of a sandy soil of the Mesa de Guanipa.

\section{MATERIALS AND METHODS}

\subsection{Soil type}

The soilsare classified in the order Entisol, subgroup Quarzipsamments (USDA Soil Taxonomy) and Arenosols (World Reference Base) enclosed in the zone of influence of the Orinoco basin, in the Mesa de Guanipa, south of the Anzoátegui State, Venezuela. They are highly weathered soils under savanna vegetation. In common they have very sandy surface layers, variable increases in clay with depth, low base saturations, a predominance of kaolinitic clays and sands dominated by quartz (Comerma and Chirinos, 1997). The phenomenon of compaction is manifested in the agricultural areas of the Mesa de Guanipa (López e $t$ al., 2015).

It has very coarse-textured soils with low water retention capacity, risks of wind erosion and the impact of raindrops and runoff, which reveals their great fragility and vulnerability. The soil acidity, as a natural condition, makes it susceptible to degradation due to acidification processes, which can be activated if they are not taken into account as part of agricultural managements.

\subsection{Sites and management practices description}

Comparisons are made between two areas with the same soil type, but under different agricultural managements (distance between sites: $100 \mathrm{~m}$ ).

\subsubsection{Disturbed soil}

In the area under conventional management $\left(8^{\circ} 50^{\prime} 48.1^{\prime \prime} \mathrm{N} ; 64^{\circ} 12^{\prime} 6.6^{\prime \prime} \mathrm{W}\right)$ during more than 30 years $(0.8 \mathrm{ha})$, tillage has been carried out at any time of year, without a consensual analysis taking into account the climate and the soil characteristics, such as optimal water content for tillage. Tillage operations involve mechanical inversion of soil and the use of disc harrow as a 
tillage implement for soil preparation and weed control. The boom of these tillage practices coincides with the rainy season. The crop rotations are nonexistent and the burning of plant residue favors the soil erosion processes by wind and water and degrade the soil structure.Central pivot irrigation system is employed without taking into account the efficient water use.

\subsubsection{Undisturbed soil}

The study includes non-mechanized area $\left(8^{\circ} 50^{\prime} 43.4^{\prime \prime} \mathrm{N} ; 64^{\circ} 11^{\prime} 59.2^{\prime \prime} \mathrm{W}\right)$ in a mixed forest $(0.53$ ha) by more two decades, without machinery traffic.

\subsection{Weather characteristics}

The large region of the Venezuelan plains belongs to the tropical-equatorial climatic zone. Annual mean temperature behavior is relatively constant (Figure 1). In contrast, precipitation constitutes the meteorological variable with the greatest intra and inter-annual variability (López et al., 2015). Total amount of annual precipitation is $1520 \mathrm{~mm}$ with a typical pattern in the Mesa de Guanipa. The rainy season is from April to October with maximum values in July and August, during this period the relative humidity is high. The dry season is from November to March, with minimum precipitation values in January, February and March, during which the relative humidity is low and evaporation reaches its maximum values, inducing a water deficit.

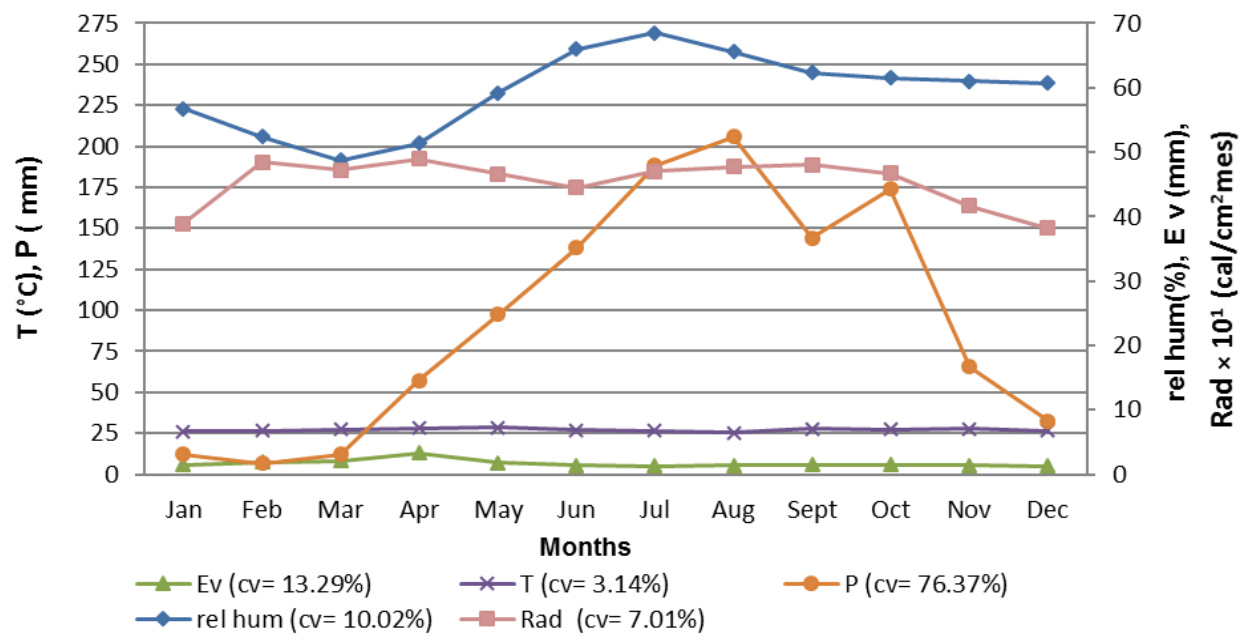

Figure 1: Monthly values ofweather data in the Mesa de Guanipa. Evaporation (Ev), temperature (T), precipitation (P), relativehumidity (rel hum), radiation (Rad) and coefficient of variation (cv).(Adapted from 16 years (1998-2014) of meteorological variables reported by INIA Agrometeorological Network, El Tigre, Anzoátegui, Venezuela)

Figure 2 allows us to synthesize the historical water deficit period from November to March and water excesses from April to October. This provides clarity concerning the scenarios and 
complexities in the use of agricultural machinery and its consequences for the sandy soils in the Mesa de Guanipa.

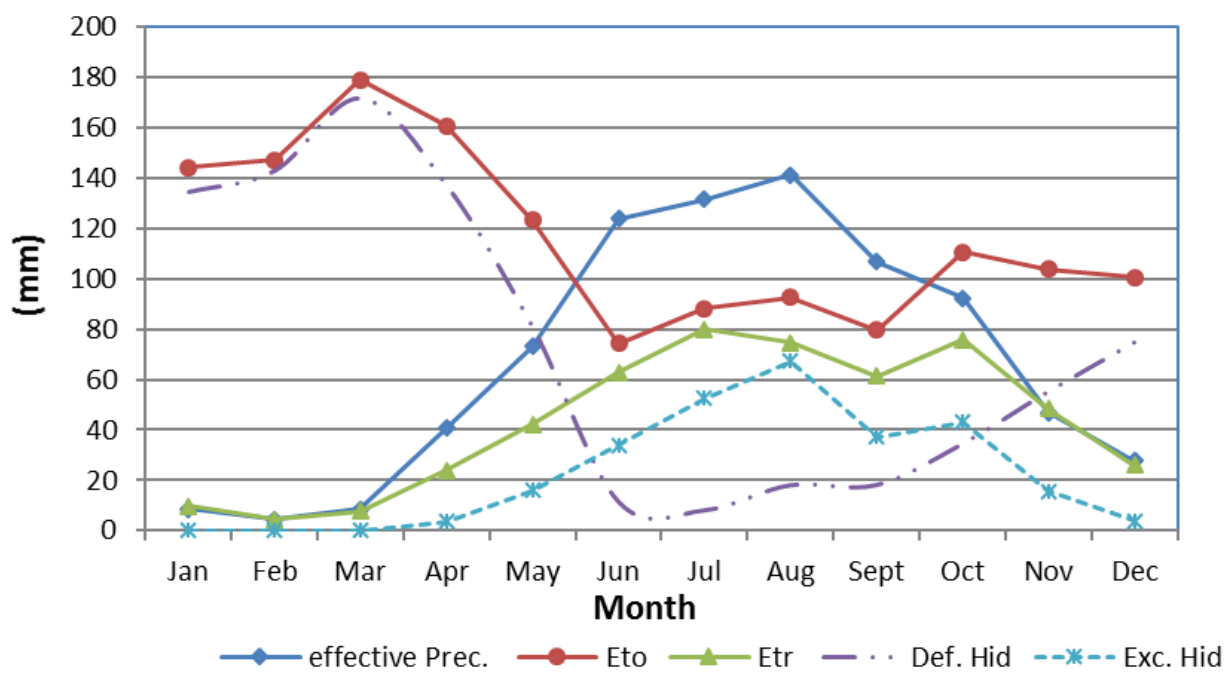

Figure 2: Water balance in the Mesa de Guanipa.

(Adapted from 16 years (1998-2014) of meteorological variables reported by INIA Agrometeorological Network, El Tigre, Anzoátegui, Venezuela).

\subsection{Experimental design}

For the selection of the points was imposed in the disturbed area a stratified-random-unaligned grid (Webster and Oliver, 1990) which combines the advantages of a regular grid and randomization. For this purpose, a main regular grid with 36 nodes was superimposed (Fig 3), made up of cells $17 \mathrm{~m}$ wide by $18 \mathrm{~m}$ long. The length and height of the cells serve the purpose of keeping the same proportions relative to the dimensions of the plot $(\approx 0.8 \mathrm{ha})$. As a result, 25 sampling points were chosen into the mechanized area. Experimental design is focused on applying geostatistical techniques for the study of variability, for example, map generation for penetration resistance, which is a research aim much more ambitious. In contrast, 10 sample points were chosen randomly in the non-mechanized soil. 


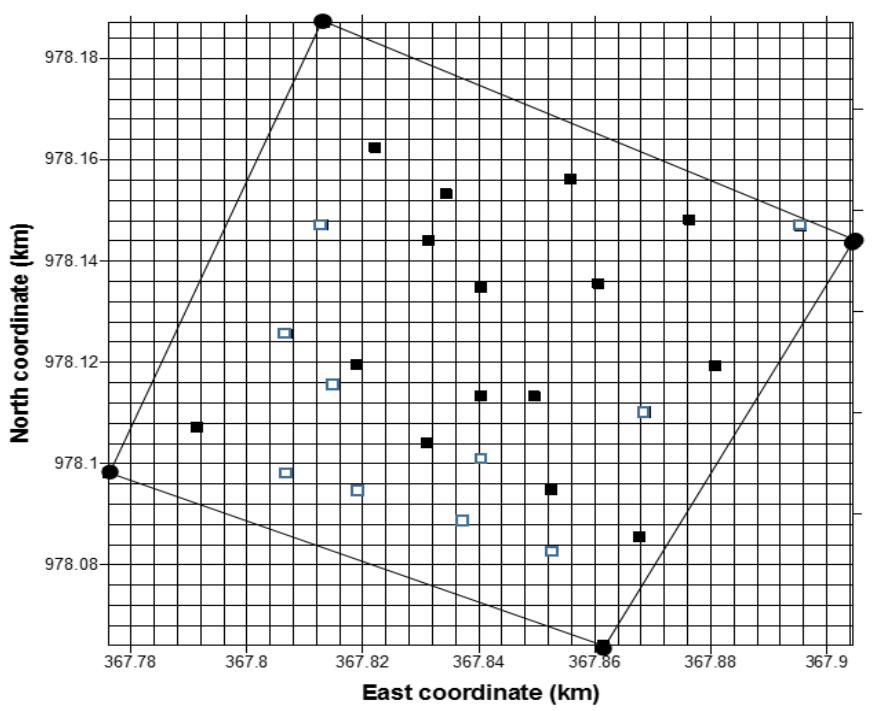

Figure 3: Site locations in the soil under conventional management. The dark circles represent the area boundary and the squares represent the sampling points. The unfilled squares are sampling points with a particular mechanical resistance behavior from 20 to 30 cm depth.

\subsection{Soil properties measured}

Selected physical, chemical, mechanical and hydraulic soil properties are shown in the Table 1.The experiment was conducted in the dry season. Soil samples were taken at $10-15 \mathrm{~cm}$ to avoid the effect of disturbances that are common close to the soil surface.

Table 1: Soil properties measured, symbol, determination method and quantification units.

\begin{tabular}{cccc}
\hline Soil properties & Symbol & Method & Units \\
\hline Particle size distribution & $\begin{array}{c}\text { Sand, Silt, clay } \\
\text { (USDA scheme) }\end{array}$ & hydrometer & $\%$ \\
Gravimetric moisture content & $\Theta_{\mathrm{g}}$ & Gravimetric & $\mathrm{g} \mathrm{g}-1$ \\
Soil Organic Matter & $\mathrm{SOM}$ & Walkley and Black (1938) & $\%$ \\
Bulk density & $\rho_{\mathrm{b}}$ & Cylinder & $\mathrm{g} \mathrm{cm}-3$ \\
Phosphorus extractable & $\mathrm{P}^{3+}$ & Olsen extracted with NaHCO, 0,5 M pH 8,5; SGCL- & $\mathrm{mg} \mathrm{kg-1}$ \\
Calcium & $\mathrm{Ca}^{2+}$ & Morgan Mod extracted with (CH3COONa) 0,125 M & $\mathrm{mg} \mathrm{kg-1}$ \\
magnesium & $\mathrm{Mg}^{2+}$ & pH 4.2 and. Soil: Solvent ratio Extrac.1:2 & \\
pH & $\mathrm{pH}$ & electrode pH meter & - \\
Penetration resistance & $\mathrm{PR}$ & soil water ratio 1:2,5SGCL-AI-002 & MPa \\
Infiltration & infiltration & double-ring infiltrometer (Bouwer 1986) & $\mathrm{mm} \mathrm{hr-1}$ \\
\hline
\end{tabular}


Dynamic cone penetrometer (DCP) have a cone penetrometer with a base area of $5.06 \times 10^{-4} \mathrm{~m}^{2}$, cone angle $60^{\circ}$, free fall distance of $0,6 \mathrm{~m}$, total mass of $7 \mathrm{~kg}$ and impact of $2.3 \mathrm{~kg}$, respectively. Number of blows were registered at $5 \mathrm{~cm}$ intervals up to $35 \mathrm{~cm}$ depth. The readings were translated into PR values using formulation 2.1 (Stolf, 1991).

$$
P R=\frac{\mathrm{M}}{(\mathrm{M}+\mathrm{m})} \frac{\mathrm{Mgh}}{\mathrm{Ax}}+(\mathrm{M}+\mathrm{m}) \frac{\mathrm{g}}{\mathrm{A}}
$$

A- basal area of the cone

g- gravity acceleration constant

$\mathrm{h}$ - height above the anvil (plate of impact)

M- mass of impact (kg)

$\mathrm{m}$ - mass of frame (unconsidered M)

$\mathrm{x}$ - penetration distant by impact or effective penetration (mm/impact)

The double ring infiltro meter is placed in both plots at $15 \mathrm{~cm}$ depth in order to distinguish possible physical peculiarities, properly of resistance to penetration. The technique is particularly suitable for surface soils that are strongly affected by compaction. A key aspect of this research is the fact of clarifying the management effects. This purpose is satisfied comparing the set of physical, chemical, mechanical and hydraulic properties measured in both areas. Measured parameters were examined using different procedures of the statistical package SPSS 16.0. In the ANOVA, Levene's test (homogeneity of variance test), as well as Brown-Forsythe, and Welch (robust tests of the equality of means) to test the hypothesis that several means are equal.

\section{RESULTS AND DISCUSSION}

\subsection{Soil physical and chemical properties}

Table 2 show the general statistics of the measured properties at both plots.

Table 2: Descriptive statistics for the disturbed and non-disturbed soils.

\begin{tabular}{|c|c|c|c|c|c|c|c|c|c|c|c|}
\hline \multirow[b]{2}{*}{ Variables } & \multirow[b]{2}{*}{$\mathbf{N}$} & \multicolumn{3}{|c|}{ Disturbed } & \multicolumn{7}{|c|}{ Non-disturbed } \\
\hline & & $\mu$ & Mín. & Max. & $\begin{array}{l}\text { C. V } \\
(\%)\end{array}$ & $\mathbf{N}$ & $\boldsymbol{\mu}$ & Mín. & Max. & $\begin{array}{l}\text { C.V } \\
(\%)\end{array}$ & $P$ value \\
\hline sand (\%) & 25 & 91.60 & 88.00 & 94.00 & 1.78 & 10 & 84.40 & 80.00 & 92.00 & 5.68 & 0.000 \\
\hline Silt $(\%)$ & 25 & 6.40 & 4.00 & 10.00 & 25.52 & 10 & 12.00 & 6.00 & 16.00 & 29.81 & 0.002 \\
\hline clay $(\%)$ & 25 & 2.08 & 2.00 & 4.00 & 19.23 & 10 & 4.00 & 2.00 & 6.00 & 31.62 & 0.020 \\
\hline$\rho_{b}\left(g \times \mathrm{cm}^{-3}\right)$ & 25 & 1.62 & 1.36 & 1.84 & 6.60 & 10 & 1.61 & 1.50 & 1.68 & 4.30 & 0.452 \\
\hline 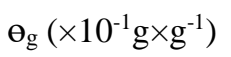 & 25 & 0.87 & 0.05 & 1.47 & 47.70 & 10 & 1.43 & 0.76 & 1.80 & 29.16 & 0.826 \\
\hline $\mathrm{P}\left(\mathrm{mg} \times \mathrm{kg}^{-1}\right)$ & 24 & 17.17 & 6.00 & 58.00 & 69.92 & 10 & 6.00 & 5.00 & 7.00 & 23.57 & 0.001 \\
\hline
\end{tabular}


International Journal of Agriculture and Environmental Research

ISSN: 2455-6939

Volume: 07, Issue: 03 "May-June 2021"

\begin{tabular}{cccccccccccc}
$\mathrm{Ca}\left(\mathrm{mg} \times \mathrm{kg}^{-1}\right)$ & 25 & 76.20 & 22.00 & 128.00 & 45.78 & 10 & 50.40 & 47.40 & 52.80 & 18.81 & 0.000 \\
$\mathrm{Mg}\left({\left.\mathrm{mg} \times \mathrm{kg}^{-1}\right)}^{25}\right.$ & 96.84 & 48.00 & 159.00 & 34.13 & 10 & 27.80 & 22.10 & 31.50 & 18.29 & 0.000 \\
$\mathrm{~S} . \mathrm{O} . \mathrm{M}(\%)$ & 25 & 0.91 & 0.62 & 1.15 & 16.10 & 10 & 3.68 & 2.46 & 5.98 & 32.73 & 0.000 \\
$\mathrm{pH} 2 \mathrm{O}(-)$ & 25 & 5.47 & 4.80 & 6.10 & 6.97 & 10 & 6.80 & 6.30 & 7.20 & 5.70 & 0.003 \\
$\Theta_{\mathrm{g} \_0-20 \mathrm{~cm}\left(\times 10^{-1}{\mathrm{~g} \times \mathrm{g}^{-1}}\right)}$ & 25 & 0.04 & 0.01 & 0.15 & 82.10 & 10 & 0.89 & 0.13 & 3.36 & 55.52 & 0.000 \\
$\Theta_{\mathrm{g} \_20-30 \mathrm{~cm}\left(\times 10^{-1}{\mathrm{~g} \times \mathrm{g}^{-1}}^{-1}\right.}$ & 25 & 0.18 & 0.06 & 0.37 & 47.41 & 10 & 0.35 & 0.18 & 0.57 & 45.15 & 0.056 \\
\hline
\end{tabular}

p: probability that the null hypothesis of equal measurement means between managements from anANOVA.

The percentage of sand, silt and clay is typical of the particle size distribution reported for regional soils (Comerma y Chirinos, 1997). Both experimental sites differ in relation to their textural composition and the chemical variables measured. The coefficient of variation indicates a greater dispersion in the fractions to the undisturbed plot. The composition of particle size is one of the properties subject to greater temporal stability, therefore the differences are due to the spatial variability.

In the case of bulk density and its gravimetric water content there are no significant differences between managements. Other studies have found similar evidences (Dao,1996; Martinez et al., 2008). Ismail et al. (1994) reported no significant difference in bulk density between tilled and untilled soils and Mubarak et al (2005) conclude that several properties, including bulk density, are not significantly different between long and short cultivation time and native vegetation.

Contrasting effects of soil management's experiments in $\rho_{b}$ are common. According to Strudley et al. (2008) the general trend of no-tillage is to increase macropore connectivity while generating inconsistent responses in total porosity and apparent density, compared to conventional practices.

The lowest $\mathrm{CVs}(<10 \%)$ are found for $\mathrm{pH}$ and bulk density. The $\mathrm{CV}$ of exchanges bases in the sandy soil under conventional managements were more than twice that of conserved sandy soil.

\subsection{Soil mechanical properties}

The number of blows with the impact mass of the DCP with depths is shown in Figure 4, which gives an idea of the contribution of energy transformed into a penetration work, whereas higher energetic requirements lead to greater penetration resistance.

In many cases the value of the number of blows is equal to zero, which is due to the weak soil structure in the first centimeters, favoring that the penetrometer searches various centimeters without the assistance of impact mass, helped only with the weight of instrument in vertical position. 


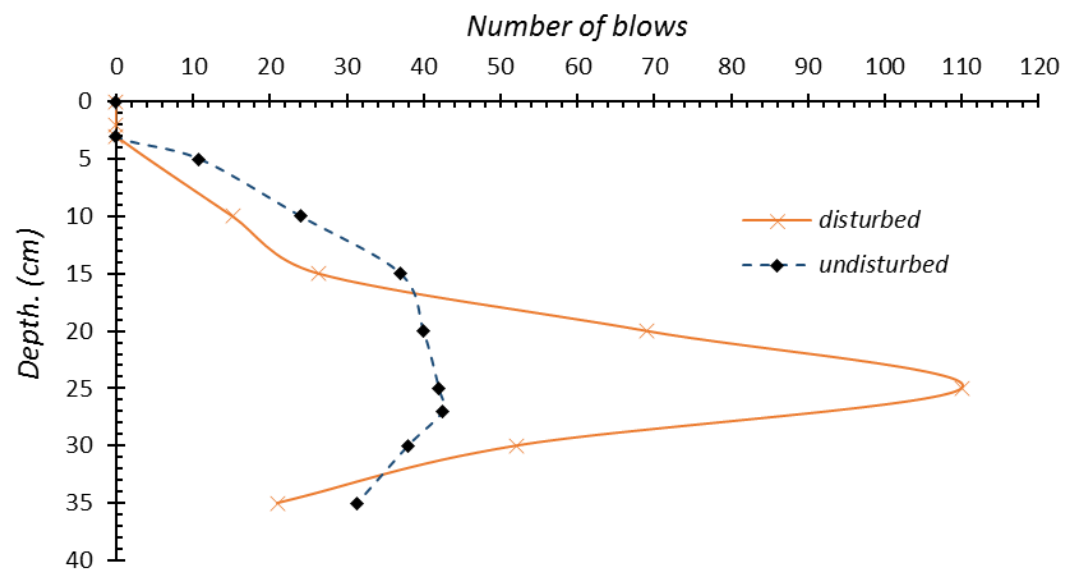

Figure 4: Number of blows of the mass of impact registered with DCP.

The number of blows experiences a tendency to increase with depth, which is more accentuated in the disturbed soil. In this soil the average value of blows registered between 15 and $20 \mathrm{~cm}$ is 70 blows, from 20 to $25 \mathrm{~cm}$ it is 106 blows and it decreases to 50 blows until $30 \mathrm{~cm}$. In contrast, the values in the undisturbed soil are 36 blows at $15 \mathrm{~cm}$ and they diminish after $25 \mathrm{~cm}$. DCP readings from 10 to $30 \mathrm{~cm}$ are different between managements (at a significance level of 99\%).

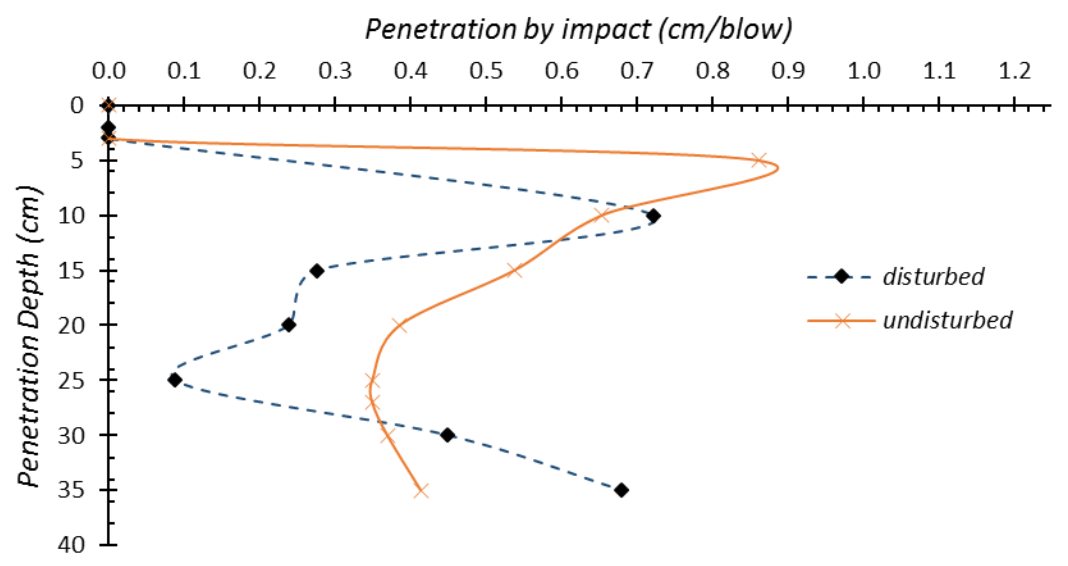

Figure 5: Penetration by impact registered with DCP.

The penetration distance by blows (cm / blows) or effective penetration of the conical tip for each blow of the impact mass in free fall is presented in Figure 5. The effective penetration from $10 \mathrm{~cm}$ exceeds $0.6 \mathrm{~cm} /$ blow in both plots, which in the disturbed case diminishes appreciably between 15 and $30 \mathrm{~cm}$. The average effective penetration is $0.27 \mathrm{~cm} /$ blows for the disturbed plot and $0.39 \mathrm{~cm} /$ blows for the undisturbed, which obey to average forces of $4.99 \mathrm{~N} / \mathrm{m}^{2}$ and $1.28 \mathrm{~N} / \mathrm{m}^{2}$, respectively. This can give an idea of the soil restrictions in both plots to the root growth. 
Figures 4 and 5reveal the occurrence in both plots of different degrees of opposition to being penetrated by the conical tip, which clearly speaks of the existence of greater resistance to penetration in the disturbed plot under conventional management, although these are not registers universally handled in the literature. Therefore, is convenient to translate the registers into RP values with the expression 2.1.

The experimental evidence of registering a number of blows equal to zero in the first centimeters is considered in this expression, reporting a value of RP different from zero, called static pressure (Figure 6). Although, the impossibility of measuring soil resistance values below this pressure constitutes a limitation in the formulation (Stolf et al., 2005). Additionally, the register can differ if different impact mass or cone area are chosen for the same soil.

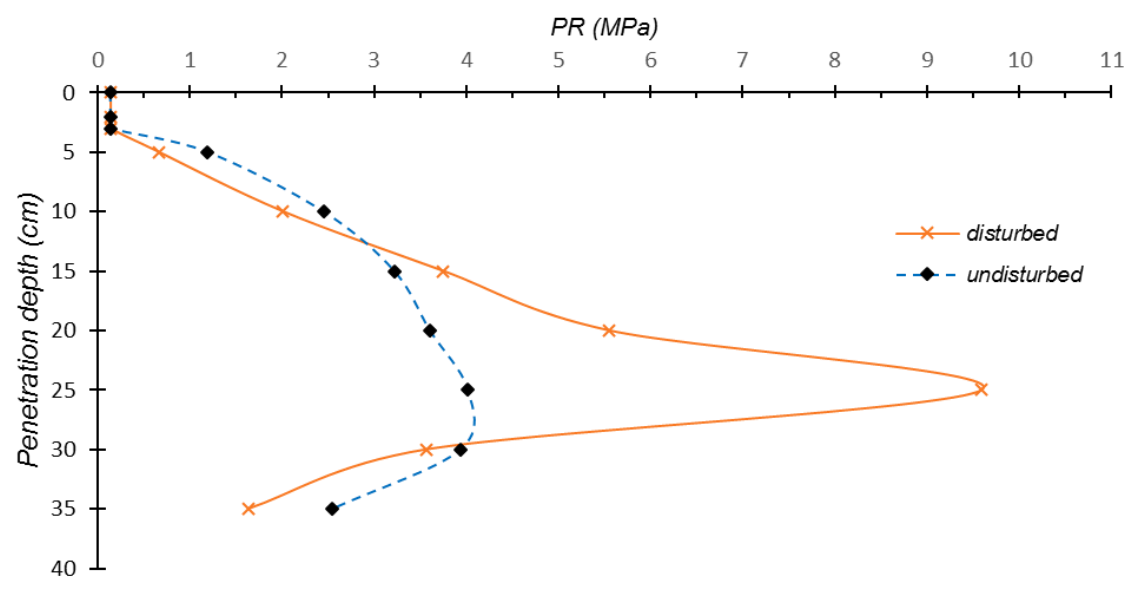

Figure 6: Penetration resistance calculated with the formulation derived by Stolf (1991).

The associated resistance value to the static pressure due to the weight of the penetrometer is equal to $0.14 \mathrm{MPa}$. A simple Anova proved that the number of blows and PR are not statistically different between managements at soil depths minor to $10 \mathrm{~cm}$. In the rest of soil depths there are significant differences between managements This is justified by the soil structure and the reaction of DCP represented by the number of blown used in the calculus of PR.

\subsection{Soil infiltration}

The soil infiltration values were measured in both areas (Figure 7), showing a significant difference in infiltration $(\mathrm{p}<0.01)$ between experimental sites.

The conserved soil initially infiltrates around $200 \mathrm{~mm} / \mathrm{hr}$, twice the value obtained in the soil under conventional management. When the infiltration rate decreases asymptotically this 
difference increases 3.5 times. When the air in the pores is replaced by water, then it infiltrates more slowly from the soil surface, tending towards the steady-state infiltration rates, which typically occur when soil is nearly saturated.

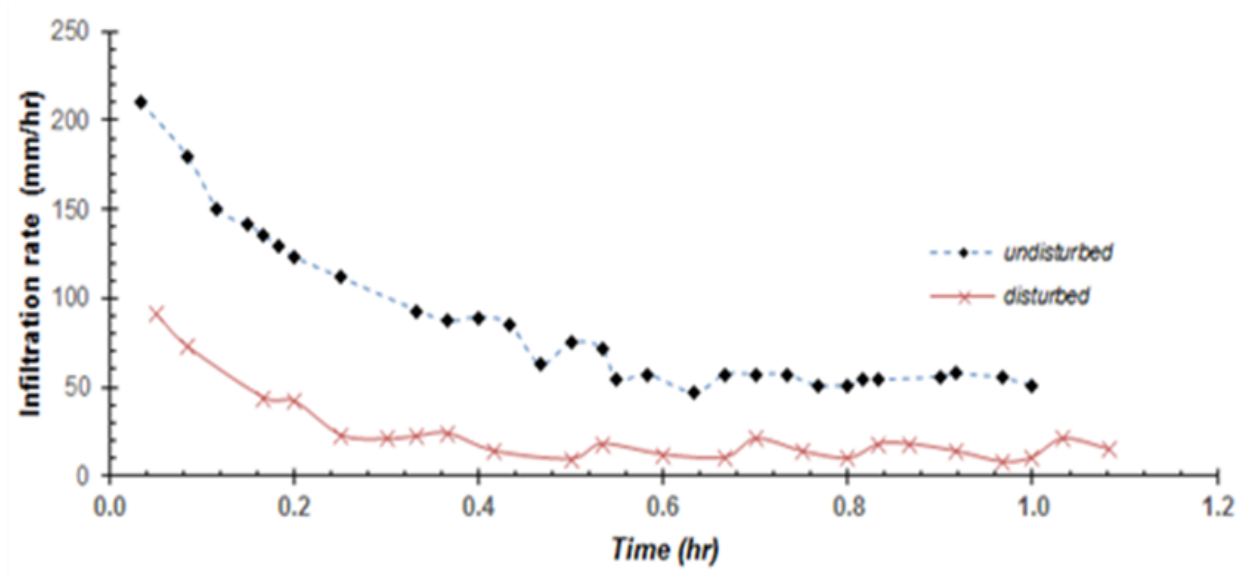

Figure 7: Infiltration rate measured with the double- ring infiltrometer.

The presence of a fine textured layer within the soil profile prevents the flow of water, even a coarse textured layer can delay infiltration in a short period of time. The soils of the Mesa de Guanipa are characterized by having an argillic horizon at depths greater than $40 \mathrm{~cm}$, but this is a source of controlled variability in the comparisons. According to Strudley et al. (2008), soil texture and soil surface conditions (e.g., cover) are independent of time at the scale of individual infiltration events, these characteristics can be assumed to be constant during the event.

To give an idea, after the soil sample were obtained water was tentatively poured into some of the holes in the mechanized plot, observing the permanence of this volume of water beyond than expected for sandy soils, characterized by being very well drained, which suggested carrying out infiltration measurements in both plots under study.

\section{DISCUSSION}

\subsection{Interaction between soil properties and managements}

To support the changing values of physical and chemical properties we also compared the measured values in representative soil profiles obtained by INIA-Anzoátegui with our corresponding values (Table 3) and generated maps.

We must pay attention to the higher values of $\rho b$ for the disturbed soil (Figure 8), indicating a close packing of elementary soil particles in soils that have been subjected to continuous cultivation. The relatively high $\rho b$ becomes evident from statistics (Table 2) and represents 
another issue of concern. Very small porosities are generally observed in sandy soils of the tropics (Lamotte et al., 1997; Lesturgez et al., 2005).

There are wide zones of the disturbed area, mainly at its southeast part (Figure 8), where the interpolated values of bulk density are higher than $1.7 \mathrm{~g} \mathrm{~cm}^{-3}$. Also higher values are reported by Bennie and Botha (1986) when recorded $1.7<\rho_{b}<1.8 \mathrm{gcm}^{-3}$ in the $0-20 \mathrm{~cm}$ layer under wheel tracks and in the 20-40 cm layer. Also Aggarwal et al. (1991) recorded $1.75<\mathrm{Db}<1.82 \mathrm{gcm}^{-3}$ in the $15-20 \mathrm{~cm}$ layer after several years of high puddling in a sandy loam soil.

In this sense, several reports confirm an interval from 1.6 to $1.7 \mathrm{~g} \mathrm{~cm}^{-3}$ how the critical value of bulk density in sandy soils (Jones, 1983; Pla, 1995; Griffith, 1977 and Reinert et al., 2001). In our study, approximately 60 percent of the values measured under conventional managements are higher than 1.6 and 28 percent are higher than $1.7 \mathrm{~g} \mathrm{~cm}^{-3}$, which is a factor limiting the root growth. Also it was corroborated in situ that the major root density of undesirable vegetation is located around $15 \mathrm{~cm}$ depth. Many extended crops in the region (Maize, bean, cassava, peanut) have maximum root depth between 0.5 to $1.5 \mathrm{~m}$ (Allen et al.,1998).

The magnitude of chemical soil properties in the disturbed soil double the referents for these soils (Table 3), but not in the undisturbed case. The soil under conventional managements have a distinctly higher phosphorous, magnesium and calcium content. The magnesium is the base with major predominance in the soil exchange complex in disagreement. With local studies (Comerma and Chirinos, 1997, Inder/INIA., 2012 and López et al., 2015).

Table 3: Chemical properties in soil of Mesa de Guanipa, Soil laboratory INIA-Anzoátegui (Inder/INIA, 2012).

\begin{tabular}{cc}
\hline Variable & values \\
\hline pH & $4,5-5,1$ \\
phosphorous & $<5 \mu \mathrm{g} / \mathrm{g}$ \\
Calcium & $10-70 \mu \mathrm{g} / \mathrm{g}$ \\
Magnesium & $5-60 \mu \mathrm{g} / \mathrm{g}$ \\
Potasium & $10-30 \mu \mathrm{g} / \mathrm{g}$ \\
Iron & $0,5-30 \mu \mathrm{g} / \mathrm{g}$ \\
Couper & $0,1-0,7 \mu \mathrm{g} / \mathrm{g}$ \\
Manganesium & $0,5-12 \mu \mathrm{g} / \mathrm{g}$ \\
Zinc & $0,1-1 \mu \mathrm{g} / \mathrm{g}$ \\
Organic matter & $0,1-1,3 \%$ \\
Aluminium exchange & $0,1-1,0 \mathrm{meq} / 100 \mathrm{~g}$ \\
Electric Conductivity & $0,1-0,3 \mathrm{dS} / \mathrm{m}$ \\
\hline
\end{tabular}

INIA: National Institute of Agricultural Research

The differences are associated with the agricultural management, abundant fertilizers and amendments, more aimed to supply the crops requirements than amending acidity. The 
inappropriate use of fertilizers, the high permeability of these soils, their low cation absorption capacity and biodegradation are the responsible for the decline in soil quality and increase the risks of agro-contamination. This reaffirms other studies that judge agricultural management in Venezuela (Pla, 1990; Rodriguez et al. 2003;) and that affirm the existence of serious soil degradation problems (Lugo-Morin, 2007).

The SOM is very low, and in some cases practically negligible, it represents another issue of agricultural soil under intensive managements. The SOM and the average $\mathrm{pH}$ under conventional managements agree with those reported in local studies (Comerma and Chirinos, 1997, Inder/INIA, 2012 and López et al., 2015).In contrast, conservation practices can increase the organic matter content alike to the soil under permanent forest.

The comparison for $\mathrm{pH}$ (Table 2) show evidence of the increase of $\mathrm{pH}$ in going on in these conserved sandy soil over the last decades, which is not common in the region of Mesa de Guanipa. The causes of the differences in $\mathrm{pH}$ for NT seem less clear. One hypothesis appoint to non-irrigation can explain such differences. In the region $\mathrm{pH}$ ranging from 5.1 to 5.3 (Silguera et al., 2014), which is the main water quality parameters in disagreement with the norms (reported in Official Gazette $\mathrm{N}^{\circ} 36.395 / 1998$ of Bolivarian Republic of Venezuela). The $\mathrm{pH}$ tendency under conservation managements is very important for alimentary independence because current values under conventional managements affects $\mathrm{pH}$-sensitive of several crops.

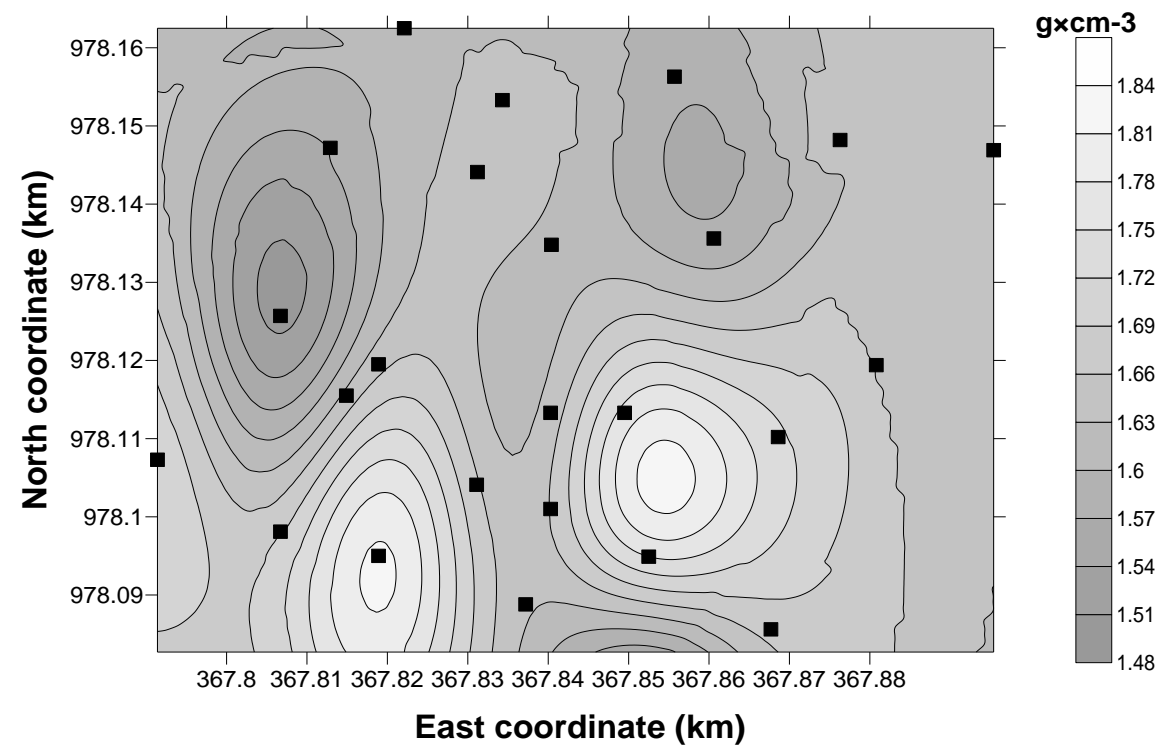

Figure 8: Kriged Map of bulk density in the disturbed soil at 10-15 cm.

\section{2. compaction and tillage}


International Journal of Agriculture and Environmental Research

ISSN: 2455-6939

Volume: 07, Issue: 03 "May-June 2021"

The subsoil compaction is a serious problem because it is expensive and difficult to alleviate and it has been recognized as a serious form of the soil degradation. According to our evidences, in 8 of the 25 sampling points in the 0.8 ha of disturbed soil were not possible register readings beyond $20 \mathrm{~cm}$ depth due to the high soil mechanical resistance and the insufficient energy of impact provided by the instrument. In these cases, the number of blows recorded was very high and the penetration by impact insignificant.

The PR is highest in the subsoil layer (>20 cm) probably because this layer supports the wheels of the tractors during ploughing. Figure 3 show that these points are located at the limits of the area. Therefore, the traffic and the proximity to the turning areas of the agricultural machinery affected the soil physical condition, leading to formation of a prominent compacted layer. Conventional management during 30 years are enough time to accumulate the combined effect of the traffic load at this soil depth. According to López et al. (2015) the presence of plow layer at depths between $15-30 \mathrm{~cm}$ is common feature in heavily mechanized areas of the Venezuelan plains. Lesturgez et al. (2005) also find the presence of a compact layer located at $20-40 \mathrm{~cm}$ depth in a sandy soil of Thailand.

In the disturbed soil until $20 \mathrm{~cm}$ depth average PR ranging from 0.14 to $5.55 \mathrm{MPa}$ when the water content ranged from 0.001 to $0.015 \mathrm{~g} \times \mathrm{g}-1$ and until $35 \mathrm{~cm}$ depth ranging from 1.63 to 9.6 MPa when the water content ranged from 0.018 to $0.037 \mathrm{~g} \times \mathrm{g}-1$. The coefficient of variation was $78.72 \%$ and $152 \%$, respectively, representing the variability in PR. In contrast, at the undisturbed area in all range of soil depth PR register values between 0.14 to $4.02 \mathrm{MPa}$ at a

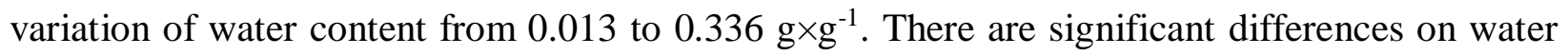
content associated with PR between managements (Table 2).

The low water content potencies the soil mechanical resistance (inversely related) in both areas, which is elevated in disturbed area by the variation of the other soil characteristics linked with soil structure and tillage (e.g. porosity, assemblage of the elementary particles) and explain that $\mathrm{PR}$ reaches inevitably high values.

Panayiotopoulos and Mullins (1985) for pure sand materials showed that these air-dry and nearly saturated sands were always found to pack more closely under a given load than the same sand at any water content. According with Bruand et al. (2005), a decrease in water content would increase frictional and cohesion forces from field capacity to intermediate water content, smaller water contents increase the frictional forces alone, disappearing the cohesion forces.

Kukal and Aggarwal (2003) recorded at field capacity a penetration resistance ranging from 3.0 to 4.5 MPa in the compacted layer and Smith et al. (1997) showed in a sandy loam soil that resistance to penetration on compressed soil cores increase from 1 to $5 \mathrm{MPa}$ over a range of 
water content of only $4 \%$ by mass. These results are more alike with PR behavior in undisturbed soil than in the disturbed.

In correspondence, To and Kay (2005) in the development of PTF from the disturbed and undisturbed data set report PR measured by cone penetrometers in the range to $8 \mathrm{MPa}$. Even 60 of them were lost because the measurement of PR was beyond the maximum measuring capacity of the transducer $(12.000 \mathrm{kPa})$.

Figure 9 shows the PR regionalized in disturbed soil. With the calculated values between 20-35 $\mathrm{cm}$ we built a semivariogram, performed spatial interpolation, and generated maps. Insights about the spatial relationships between the bulk density and PR are provided in Figure 8 and 9.

In the same disturbed points stated above are reported higher values, although in most of them the PR is above the critical values (7.2 MPa) for sandy soil with clay content between 5 and 10 $\%$ (Chaudhari et al., 2013).

We must mention that the calculated values do not take into account the value corresponding to the friction force between the stem of the equipment and soil. This unconsidered force is dependent on the relationship between the length and diameter of the stem in contact with the soil and the basal area of the cone (Ramos et al., 2014). Furthermore, the root adaptability under current physical conditions is not taken into account in the study. However, it is more appropriate to pay attention to the physical evidence and trends aggravated by the conventional managements, which have been correctly interpreted by the DCP.

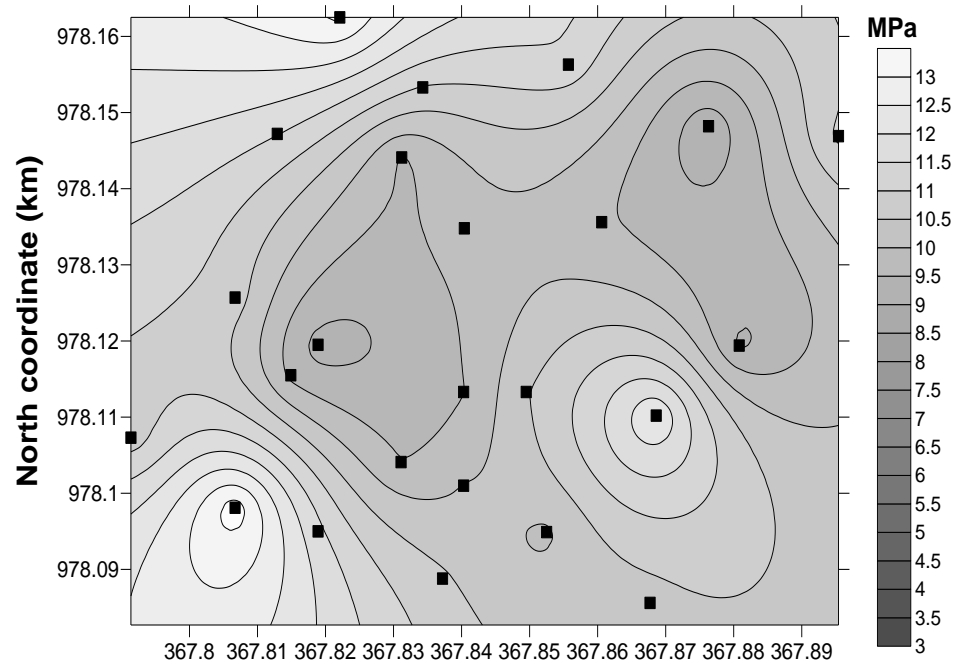

East coordinate $(\mathrm{km})$

Figure 9: Kriged Map of penetration resistance in the disturbed soil at 20-30 cm. 
International Journal of Agriculture and Environmental Research

ISSN: 2455-6939

Volume: 07, Issue: 03 "May-June 2021"

It is difficult to provide clear guidelines about how the observed patterns are affecting root or crop growth and yields under the current conventional managements, but the adoption of conservation practices is crucial for their sustainability on the medium and long term.

\section{3 soil infiltration and managements}

Many usual tillage operations in the region induce through a succession of traffic loads the usual massive aspect in the soil profile. It is occurring at varying depths. Is common to observe plow pans, harrow pans and traffic pans (López et al., 2015). Mechanical compaction in sandy soils affects the large pores down to the small pores that result from the arrangement of the skeleton particles (sand and silt) within the clay fraction, which is possible because of the small cohesion between the skeleton particles (Bruand et al. 2005). According to Poiseuille's law, water flow rate in the tubular pores is proportional to the square of the pore diameter.

In this sense, mechanical compaction influences the soil infiltration. For a better compression, the stabilized infiltration rate is a function of the pore configuration and must remain stable over time unless the structure is altered by machinery traffic. In this study, the water infiltrates faster in the conserved soil than in the intensively tilled and massively compacted soil. Also Azooz and Arshad (1996 and 2001) measured a significantly lower infiltration rate under conventional tillage than in no-tillage in silty and silty sandy soils of northwestern Canada.

The infiltration rates in highly permeable soils must be high. Values above $100 \mathrm{~mm} / \mathrm{hr}$ are invariably associated with coarse textures, while below $50 \mathrm{~mm} / \mathrm{hr}$ they are associated with groups of medium and fine textures (Diamond and Shanley, 1998). The infiltration rate measured in the mechanized soil are in disagreement with data showed by these authors. In addition, it does not satisfy the steady infiltration rates given for general soil textural groups (Hillel,1998). According this author sandy group must exceed $20 \mathrm{~mm} / \mathrm{hr}$. In the conventional managements the soil infiltration capacity decreased and consequently its values are not typical of its textural group.

When rainfall occurs at a rate that exceeds the soil's infiltration capacity, runoff moves downslope or ponds on the surface of level land. When runoff occurs on bare or poorly vegetated soil, erosion occurs. Runoff promote leaching nutrients, chemicals, and soil, resulting in decreased soil productivity, offsite sedimentation of water bodies, and diminished water quality.

Pitt et al. (1999) obtained that the structural state is the main cause of infiltration differences for a high number of sandy soils grouped by wet, dry and compaction, as well as the fact that the initial and final average infiltration velocity of the non-compacted exceeds the value of compacted in 3 and 8 times, respectively.

In contrast, according to Agrawal and Kunar (1976), Agrawal et al. (1987), Agrawal (1991) and Arora et al. (2005) the compaction that reduces the volume and continuity of large pores, would 
International Journal of Agriculture and Environmental Research

ISSN: 2455-6939

Volume: 07, Issue: 03 "May-June 2021"

increase water retention and reduce water infiltration and saturated hydraulic conductivity in highly permeable deep sandy soils. Compaction would save irrigation water by $15-36 \%$ and increase productivity by $30-50 \%$. In this sense, Martinez et al. (2008) report that soil water infiltration and coarse porosity decreased under NT as compared to CT. Although it can disappear rapidly and constitute an apparent advantage.

It is necessary to carry out future studies to evaluate the soil water availability and crop yields, to categorically discern if the current penetration resistance and infiltration capacity, induced by the use and handling of machinery, constitute desired effects or not for crops planted in regional soils.

\section{CONCLUSIONS}

There are significant differences between disturbed and no-disturbed sandy soil in the phosphorous content, calcium, magnesium, organic matter, soil compaction resistance and infiltration rate. These differences are related to conventional managements that affect the soil attributes of agricultural soils in the Mesa de Guanipa. Bulk density and penetration resistance exceed critical values in several sites, therefore representing limiting factors. However, there are no significant differences for the bulk density between managements. The increasing penetration resistance and decreasing soil infiltration are the most concerning degradation problems in the regional soils.

Soil degradation must be reversed with tillage operations to loose condensed and impermeable soil horizons that restrict or prevent root penetration, movement of fluids, and activities of soil organisms, without burning crop residues to provide the incorporation of plant cover and organic matter while helping to mitigate erosive processes and stabilize the infiltration capacity during the occurrence of meteorological events, as well as carrying out irrigation planning that takes into account the climatic characteristics and crop water requirements.

\section{REFERENCES}

Agrawal R.P., Kumar, 1976. Nitrogen movement as influenced by initial soil wetness, soil texture and soil structure of surface layer. In: S.P. Sen, Y.P. Abrol and S.K. Sinha (Editors), Nitrogen Assimilation and Crop Productivity. Proc. Natl. Symp. Hisar, India, Associated Publishing Co., New Delhi, pp. 260-268.

Agrawal R.P., Jhorar B.S., Dhankar J.S., Raj M., 1987. Compaction of sandy soils for irrigation management. Irrigation Science, 8, 227-232.

Aggarwal R.P., 1991 - Water management in sandy soils by compaction. Soil and Tillage Research, 19, 121-130. 
International Journal of Agriculture and Environmental Research

ISSN: 2455-6939

Volume: 07, Issue: 03 "May-June 2021"

Allen, R. G.; Pereira, L. S.; Raes, D.; Smith, M., 1998. Crop evapotranspiration: Guidelines for computing crop water requirements. FAO Irrigation and Drainage Paper, 56. FAO, Rome.

Arora V.K., Gajri P.R., Uppal H.S., 2005 - Puddling, irrigation, and transplanting-time effects on productivity of rice-wheat system on a sandy loam soil of Punjab, India. Soil and Tillage Research, In Press.

Azooz, R.H., Arshad, M.A., 1996. Soil infiltration and hydraulic conductivity under long-term no-tillage and conventional tillage systems. Can. J. Soil Sci. 76 (2), 143-152.

Azooz, R.H., Arshad, M.A., 2001. Soil water drying and recharge rates as affected by tillage under continuous barley and barley-canola cropping systems in northwestern Canada. Can. J. Soil Sci. 81 (1),45-52.

Bennie A.T.P., Botha F.J.P., 1986 - Effect of deep tillage and controlled traffic on root growth, water-use efficiency and yield of irrigated maize and wheat. Soil and Tillage research, 7, $85-95$.

Bouwer, H. (1986). Intake rate: Cylinder infiltrometer. In: Klute, A., ed., "Methods of Soil Analysis," Monograph No. 9. Am. Soc. Agron., Madison, WI.

Bruand, A., Hartmann, C. and Lesturgez, G.2005. Physical properties of tropical sandy soils: A large range of behaviours. Management of Tropical Sandy Soils for Sustainable Agriculture. A holistic approach for sustainable development of problem soils in the tropics., Khon Kaen, Thailand. 2005, 27.11.2005 au 2.12.2005. <hal-00079666>.

Cárdenas, A.L., C.R.Campos and F.Escamilla.2000. Geografía de Venezuela.Fondo Editorial de la Universidad Pedagógica Experimental Libertador y la Fundación Programa de Formación Docente. Caracas. Distrito Federal.

Chaudhari, P. R., Ahire, D. V., Chkravarty, M. and Maity, S, 2013: "Soil Bulk Density as related to Soil Texture, Organic", International Journal of Scientific and Research Publications, ISSN 2250-5289, 3(2), 45-58.

Comerma, J.; Chirinos, A., 1997: Características de algunos sueloscon y sin horizonte argílico en las Mesas Orientales de Venezuela, Agronomía Tropical, 27(2): 181-192, ISSN: 0002$192 X$.

Dao, T.H., 1996. Tillage system crop residue effect on surface compaction of a paleustoll. Agron. J. 88, 141-148.

Diamond J. and Shanley T., 1998. INFILTRATION RATE ASSESSMENT OF SOME MAJOR SOILS. The Science of Farming and Food, ISBN No. 1901138954. 
International Journal of Agriculture and Environmental Research

ISSN: 2455-6939

Volume: 07, Issue: 03 "May-June 2021"

FAO. 1994. Erosión de los suelos en América Latina. Suelos y Aguas. p. 33-52.

Griffith,D.R.,1977. Conservation tillage in the eastern corn belt.”, J. Soil Water Conserv., 32: 20-28.

Hillel, D., 1998. Environmental Soil Physics, Academic Press, San Diego, CA.

Hossne, A. 2006. Las rastras de disco y sus perspectivas económicas en Venezuela. Revista Científica UDO Agrícola Universidad de Oriente, 6(1):41-46.

INDER/INIA, 2012: El cultivo de soya en la Mesa de Guanipa. Ed. Ministerio del Poder Popular para la Agricultura y Tierra, 2da ed., Caracas Venezuela, 6-10 p.

Ismail, I., Belvins, R.L., Frye, W.W., 1994. Long-term no-tillage effect on soil properties and continuous corn yield. Soil Sci. Soc. Am. J. 58, 193-198.

Lamotte M., Bruand A., Humbel F.X., Herbillon A.J., Rieu M., 1997: A hard sandy-loam soil from semi-arid Northern Cameroon: I. Fabric of the groundmass. European Journal of Soil Science, 48, 213-225.

Lesturgez, G.; C. Hartmann; D. Tessier and R. Poss. 2005. Compaction processes in a tilled Sandy soil. http://www.fao.org/docrep/010/ag125e/AG125E15.htm

López R.; Hétier J.M; López D.; Shargel, R. y Zinck, A., 2015.Tierras Llaneras de Venezuela...tierras de buena esperanza. Consejo Editorial Universidad de los Andes, 1ra edición.

Lozano Z., Lobo D. and Pla I., 2002. Susceptibilidad a la degradación física de Anfisoles de los llanoscentrales y occidentales de Venezuela", Documento de Trabajo. Maracay. Venezuela.

Lugo- Morin, D.R., 2007. Evaluación del riesgo agroambiental de los suelos de las comunidades indígenas del estado Anzoátegui, Venezuela. Ecosistemas 16 (1): 69-79.

Kukal S.S., Aggarwal G.C., 2003: Puddling depth and intensity effects in rice - wheat system on a sandy loam soil. I. Development of subsurface compaction. Soil and Tillage Research, $72,1-8$.

Martinez E., Fuentes J.P., Silva P., Valle S. and Acevedo E., 2008.Soil physical properties and wheat root growth as affected by no-tillage and conventional tillage systems in a Mediterranean environment of Chile.Soil \& Tillage Research 99, 232-244.

Mazzani, B. 1999. Los suelos y su manejo en los llanos centro-occidentales. En: Investigación y tecnología del cultivo del ajonjolí en Venezuela. Caracas: Conicit, Fundacite-Aragua. 
International Journal of Agriculture and Environmental Research

ISSN: 2455-6939

Volume: 07, Issue: 03 "May-June 2021"

Mogollón, L.F.; Comerma, J.A.,1994: Suelos de Venezuela, Ed. Exlibris, PDVSA PALMAVEN, $21 \mathrm{p}$.

Mubarak A.R., Elshami O.M.E.and Azhari A.A., 2005. Long- and short-term effects of cultivation on properties of a Vertisol under sugarcane plantation. Soil \& Tillage Research 84 (2005) 1-6.

Panayiotopoulos K.P., Mullins C.E., 1985. Packing of sands. Journal of Soil Science, 36, 129139.

Pitt R., Lantrip J. Harrison R.,1999. Infiltration Through Disturbed Urban Soils and CompostAmended Soil Effects on Runoff Quality and Quantity. https://www.researchgate.net/publication/268296980.

Pla, I. 1990. La Degradación y el Desarrollo Agrícola de Venezuela. Agronomía Tropical40: 7 27.

Ramos, c.e.; Martínez, a.; García delafigal, A., $\quad$ 2014: Modelo paraelcálculodelaresistenciadel suelo alapenetracióndesondas.ParteI:sondascónicas”,Revista Ciencias Técnicas Agropecuarias, 2071-0054.

Reinert, D.; Reichert, J.; Aita, C.; Cubilla, M., 2001. Una alternativa para disminuir la compactaciónen siembra directa, Revista El Productor.

Rodríguez, T., Sanabria, D. y Navarro, L., 2003.Nuevos enfoques en el manejo de sabanas en los llanos orientales venezolanos. Centro de Investigaciones Agropecuarias del Estado Anzoátegui. Rev. Divulga $\mathrm{N}^{\circ}$ 52. Disponible En: http://www.ceniap.gov.ve/bdigital/fdivul/fd52/sabanas.htm.

Silguera, J., Benítez, Iramos, L. B., González L., O. M. E., de León J. B., 2014. Evaluación físico química del agua de consumo de los pozos del municipio San José de Guanipa, Estado Anzoátegui, Venezuela. HIGIENE Y SANIDAD AMBIENTAL, Volumen 14, número 3, páginas 1213-1234.

Smith C.W., Johnston M.A., Lorentz S., 1997. The effect of soil compaction and soil physical properties on the mechanical resistance of South African forestry soils. Geoderma, 78, 93-111.

Stolf, R. 1991. Teoria e teste experimental de fórmulas de transformacao dos dadas de penetrometro de impacto em resistencia do solo.Rev. Bras. Cienc. Solo 15:229-235.

Stolf, R., Reichardt, K., Vaz, C.P.M., 2005: "Response to "Comments on 'Simultaneous Measurement of Soil Penetration Resistance and Water Content with a Combined 
Penetrometer-TDR Moisture Probe' and 'A Dynamic Cone Penetrometer for Measuring Soil Penetration Resistance” Soil Sci. Soc. Am. J., DOI:10.2136/sssaj2005.0926., 69(3): 926.

Strudley, M.W., Green, R.T., Ascough II, J.C, 2008. Tillage effects on soil hydraulics properties in space and time: State of the science. Soil \& Tillage Research 99, 4-48.

To, J., Kay, B.D., 2005. Variation in penetrometer resistance with soil properties: the contribution of effective stress and implications for pedotransfer functions. Geoderma 126 (2005) $261-276$.

Walkley, A., Black, I.A., 1934. An examination of Degtjareff method for determining soil organic matter and a proposed modification of the chromic acid titration method. Soil Sci.37, 29-37.

Webster, R., Oliver, M.A., 1990. Statistical Methods in Soil and Land Resource Survey. Oxford University Press, Oxford, 316 pp. 